\title{
Bio-Efficacy of Bio-Pesticides against Aphid, Aphis craccivora Koch Infesting Fenugreek
}

\author{
R.M. Sarvaiya ${ }^{1 *}$, N.P. Rathod ${ }^{1}$ and R.M. Patel $^{2}$ \\ ${ }^{1}$ Polytechnic in Agriculture, Dalkhaniya Road, Junagadh Agriculture University, \\ Dhari-365640 dis-Amreli (Gujarat), India \\ ${ }^{2}$ (Plant Protection), Krishi Vigyan Kendra, Anand Agriculture University, Devataj -387240 \\ Dis-Anand (Gujarat), India \\ *Corresponding author
}

\section{A B S T R A C T}

\begin{tabular}{|l|l}
\hline $\begin{array}{l}\text { Keywords } \\
\begin{array}{l}\text { Fenugreek, Aphis } \\
\text { craccivora, Bio-efficacy, } \\
\text { ICBR }\end{array}\end{array}$ & $\begin{array}{l}\text { Among seven bio-pesticides evaluated against A. craccivora on fenugreek, } \\
\text { azadirachtin } 0.0006 \% \text {, neem oil } 0.3 \% \text { and garlic bulb extract } 3 \% \text { were } \\
\text { found most effective in suppressing the aphid population. Maximum seed } \\
\text { yield was registered in plots treated with azadirachtin followed by neem oil } \\
\text { and garlic bulb extract. The maximum net realization was obtain in the }\end{array}$ \\
\cline { 1 - 1 } $\begin{array}{l}\text { Accepted: } \\
\begin{array}{l}\text { 20 September } 2018 \\
\text { Available Online: } \\
10 \text { October } 2018\end{array}\end{array}$ & $\begin{array}{l}\text { treatment of azadirachtin and maximum ICBR was registered in neem oil } \\
0.3 \% .\end{array}$ \\
\hline
\end{tabular}

\section{Introduction}

Fenugreek, Trigonella foenum-graecum (L.) is a self-pollinated annual dicotyledonous leguminous crop belonging to the sub family Papilionaceae under the family Fabaceae. It is known as Methi (Hindi, Gujarati, Urdu, Punjabi and Marathi), Hulba (Arabic), Moshoseitaro (Greek), Uluva (Malayalam), Shoot (Hebrew), Dari (Persian) and Hayseed in English. Fenugreek is one of the oldest medicinal plants from Fabaceae family originated in Central Asia-4000 BC (Ahmad et al., 2015). The major producers of fenugreek in the worlds are India, Morocco, Spain, Turkey, China and Pakistan. In India, fenugreek is mainly cultivated in Rajasthan, Gujarat, Madhya Pradesh and Uttar Pradesh. Rajasthan which accounts about 75 to 85 per cent of the total production, while in Gujarat, it is mainly grown in Banaskantha and Mehsana districts and sporadically in Saurashtra region (Anon., 2015). Insect pests attacking the fenugreek crop are Aphid, Aphis craccivora; Koch, Leaf hopper, Empoasca kerri Pruthi; Whitefly, Bemisia tabaci Gennadius; Leaf miner Liriomyza congesta Becker, Leaf eating caterpillar, Spodoptera litura Fabricius, Weevil, Hypera branneipennis Boh.; Mite, Petrobia lateens Muller and Thrips, Thrips tabaci (Manjula et al., 2015). 


\section{Materials and Methods}

In order to determine the relative bio-efficacy of bio-pesticides against A. craccivora on fenugreek (Gujarat Methi-2), a field experiment was conducted during Rabi 201516 at Main Vegetable Research Station, Anand Agricultural University, Anand. Requirement of gross plot area was $3.0 \mathrm{~m} \mathrm{x}$ $1.8 \mathrm{~m}$ and net pot area was $2.8 \mathrm{~m} \mathrm{x} 1.2 \mathrm{~m}$ for each treatment plot. Seven different biopesticides viz., NSKE 5\%, Neem oil $0.3 \%$, Azadirachtin (0.15 EC) $0.0006 \%$, Garlic bulb extract $3 \%$, Beauveria bassiana $2 \times 10^{8} \mathrm{cfu} / \mathrm{g}$, Lecanicillium lecanii $2 \times 10^{8} \mathrm{cfu} / \mathrm{g}$ and Tobacco decoction $2 \%$ were evaluated in comparison with control (water spray) for their relative bio-efficacy against $A$. craccivora on fenugreek crop.

All the recommended agronomical practices were adopted for crop grown. First and second bio-pesticides sprays were applied during January 18, 2016 and January 29, 2016. For the purpose of recording the observations, five plants were randomly selected from net plot area and tagged. Observations on number of aphids present on $10 \mathrm{~cm}$ terminal part of central shoot of each tagged plant were recorded prior as well as 3, 5, 7 and 10 days after each spray. Effectiveness of the treatments was judged based on the efficacy of the bio-pesticides against A. craccivora, seed yield and economics.

The data on number of aphids per $10 \mathrm{~cm}$ central shoot were analyzed after transforming them into square root while, the data on yield were analyzed without any transformation. The data were analyzed by using RBD design periodically, pooled over periods and pooled over sprays to see the consistency of the treatment performance. For determine of increase in yield over control and avoidable losses, following formula given by Poul (1976) were used:
Yield of treatment - Yield of control Per cent increase in

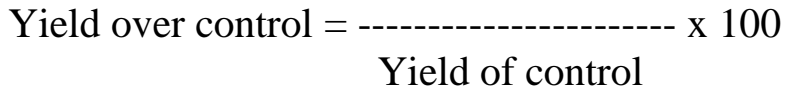

Highest yield in treated plot Yield in treated plot

Avoidable loss $(\%)=$--------------- x 100

Highest yield in treated plot

\section{Results and Discussion}

The results presented in Table 1. There was non-significant difference among different treatments before spay indicating uniform distribution of aphid population among different treatments. Aphid population recorded at 3 DAS clearly indicated that it was significantly decreased in all the bio-pesticides treatments over untreated control. Among the various bio-pesticides, Azadirachtin had minimum number of aphids $(16.89 / 10 \mathrm{~cm}$ central shoot) and it was at par with neem oil (22.44), garlic bulb extract (23.02) and neem seed kernel extract (26.33). The maximum population (29.64) was recorded in the plot treated with $L$. lecanii and proved to be least effective. More or less similar type of result was observed at fifth, seventh, tenth as well as pooled over period of first and second sprays. Aphid population was slightly increased between seventh and tenth day after both spray in all treatments. It means bio-pesticides are effectively control the aphid up to seven day, thereafter its effectiveness were decreased. The data on aphid populations pooled over periods and sprays indicated that all the bio-pesticides recorded significantly less aphid population than control. A significantly less number of aphids (6.26 aphid/ central shoot) was recorded in plots treated with azadirachtin showing its superiority over other treatments. Neem oil, garlic bulb extract and neem seed kernel extract were also found better treatments next to azadirachtin in reducing the aphid incidence. 
Table.1 Periodical population of A. craccivora on fenugreek in different bio-pesticides treatment

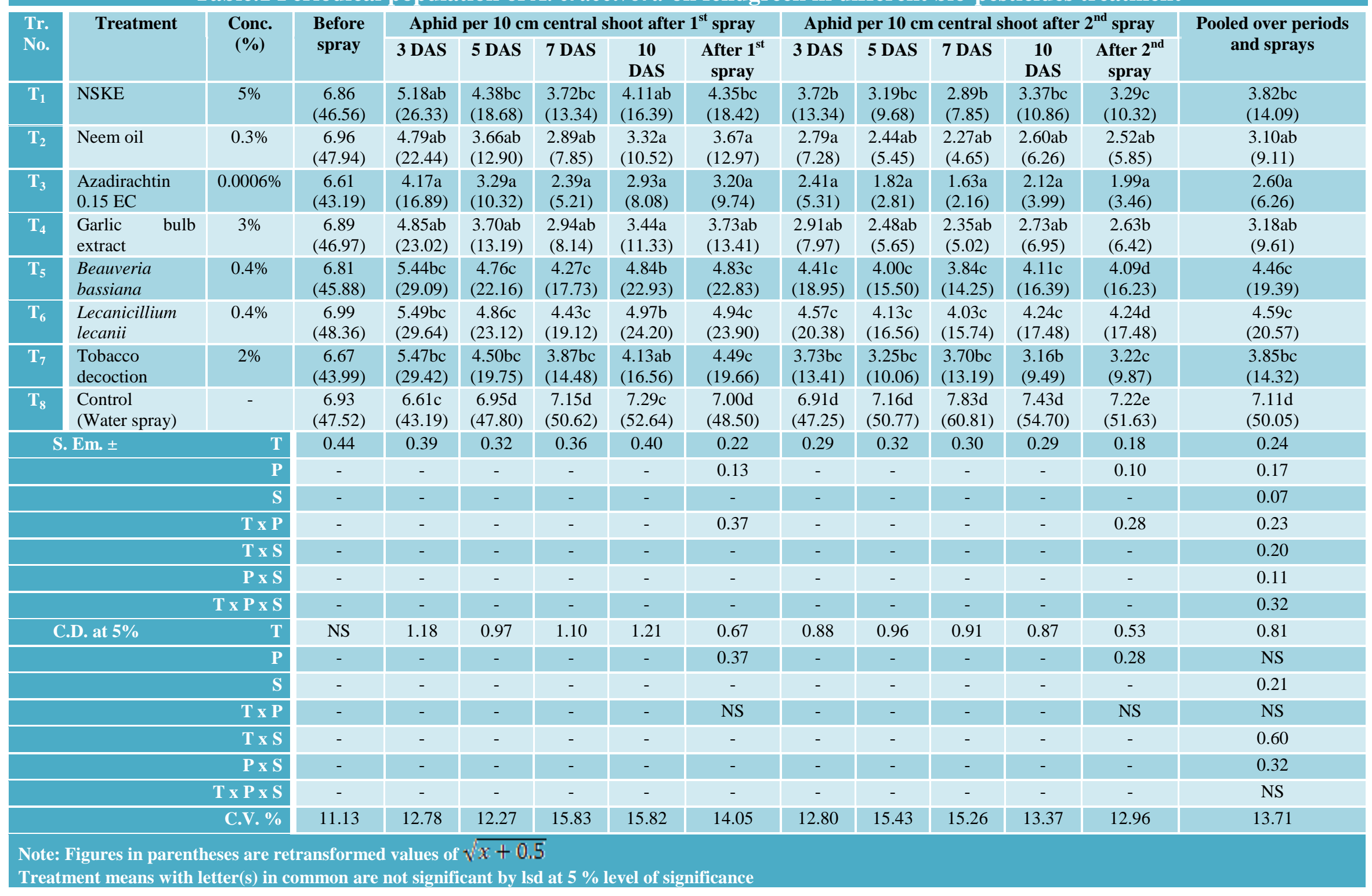




\begin{tabular}{|c|c|c|c|c|}
\hline Tr. No. & Treatments & Seed yield (q/ha) & $\begin{array}{l}\text { Increase in } \\
\text { yield over } \\
\text { control }(\%)\end{array}$ & Avoidable losses (\%) \\
\hline 1 & 2 & 3 & 4 & 5 \\
\hline$\overline{T_{1}}$ & NSKE $5 \%$ & $16.12 \mathrm{ab}$ & 22.12 & 6.61 \\
\hline$\overline{T_{2}}$ & Neem oil $0.3 \%$ & $16.87 \mathrm{ab}$ & 27.80 & 2.26 \\
\hline $\mathbf{T}_{3}$ & Azadirachtin $0.0006 \%$ & $17.26 \mathrm{a}$ & 30.76 & 0.00 \\
\hline$\overline{T_{4}}$ & Garlic bulb extract $3 \%$ & $16.77 \mathrm{ab}$ & 27.05 & 2.84 \\
\hline $\mathbf{T}_{5}$ & Beauveria bassiana WP $0.4 \%$ & $15.13 \mathrm{abc}$ & 14.62 & 12.34 \\
\hline$\overline{T_{6}}$ & Lecanicillium lecanii WP $0.4 \%$ & $14.83 \mathrm{bc}$ & 12.35 & 14.08 \\
\hline$\overline{\mathbf{T}_{7}}$ & Tobacco decoction $2 \%$ & $16.02 \mathrm{ab}$ & 21.36 & 7.18 \\
\hline$\overline{T_{8}}$ & Control & $13.20 \mathrm{c}$ & 0.00 & 23.52 \\
\hline \multicolumn{2}{|l|}{ S. Em. \pm} & 0.79 & - & - \\
\hline \multicolumn{2}{|l|}{ C.D. at $5 \%$} & 2.39 & - & - \\
\hline \multicolumn{2}{|l|}{ C. V. $(\%)$} & 8.64 & - & - \\
\hline
\end{tabular}


Table.3 Economics of different bio-pesticidal treatments evaluated against $\boldsymbol{A}$. craccivor $a$ on fenugreek

\begin{tabular}{|c|c|c|c|c|c|c|c|c|}
\hline Treatments & $\begin{array}{l}\text { Quantity of } \\
\text { pesticides } \\
\text { (Lit. or } \\
\text { kg/ha) } \\
\text { required for } \\
\text { two spray }\end{array}$ & $\begin{array}{l}\text { Cost of } \\
\text { treatments } \\
\text { for two spray } \\
(₹ / h a)\end{array}$ & $\begin{array}{l}\text { Total cost of } \\
\text { treatments } \\
\text { including } \\
\text { labour charges } \\
\text { (₹/ha) }\end{array}$ & $\begin{array}{l}\text { Yield } \\
\text { (q/ha) }\end{array}$ & $\begin{array}{l}\text { Net gain } \\
\text { over } \\
\text { control } \\
(q / h a)\end{array}$ & $\begin{array}{c}\text { Total } \\
\text { realization } \\
\text { over control } \\
(₹ / h a)\end{array}$ & $\begin{array}{c}\text { Net } \\
\text { realization } \\
\text { over } \\
\text { control }\end{array}$ & ICBR \\
\hline 1 & 2 & 3 & 4 & 5 & 6 & 7 & 8 & 9 \\
\hline NSKE 5\% & $50 \mathrm{~kg}$ & 1000 & 1894 & 16.12 & 2.92 & 8760 & 6866 & $1: 4.62$ \\
\hline Neem oil $0.3 \%$ & 3 Lit. & 450 & 1344 & 16.87 & 3.67 & 11010 & 9666 & $1: 8.19$ \\
\hline $\begin{array}{l}\text { Azadirachtin } \\
0.0006 \%\end{array}$ & 4.0 Lit. & 2400 & 3294 & 17.26 & 4.06 & 12180 & 8886 & $1: 3.69$ \\
\hline $\begin{array}{ll}\text { Garlic } & \text { bulb } \\
\text { extract 3\% } & \end{array}$ & $30 \mathrm{~kg}$ & 2400 & 3294 & 16.77 & 3.57 & 10710 & 7416 & $1: 3.25$ \\
\hline $\begin{array}{l}\text { Beauveria } \\
\text { bassiana } \\
0.4 \%\end{array}$ & $4.0 \mathrm{~kg}$ & 880 & 1774 & 15.13 & 1.93 & 5790 & 4016 & $1: 2.26$ \\
\hline $\begin{array}{l}\text { Lecanicillium } \\
\text { lecanii WP } 0.4 \%\end{array}$ & $4.0 \mathrm{~kg}$ & 920 & 1814 & 14.83 & 1.63 & 4890 & 3076 & 1:1.69 \\
\hline $\begin{array}{l}\text { Tobacco } \\
\text { decoction 2\% }\end{array}$ & $20 \mathrm{~kg}$ & 200 & 1094 & 16.02 & 2.82 & 8460 & 7366 & $1: 6.73$ \\
\hline Control & - & - & - & 13.20 & - & - & - & - \\
\hline
\end{tabular}


The treatments of B. bassiana and L. lecanii had significantly higher population of aphids (19.39 and 20.57 aphids/central shoot, respectively) and proved inferior in controlling the pest.

The data (Table 2) on seed yield showed higher seed yield in all the treated plots than untreated check. The maximum seed yield (17.26 q/ha) was found in plots sprayed with azadirachtin followed by neem oil (16.87 $\mathrm{q} / \mathrm{ha}$ ) and other all bio-pesticides treated plots. A minimum seed yield (14.83 q/ha) was obtained in L. lecanii followed by $B$. bessiana (15.13 q/ha).

The maximum per cent of increase in yield over control was found in plots treated with azadirachtin (30.76) followed by neem oil (27.80) and garlic bulb extract (27.05). Minimum per cent of increase in yield (12.35) over control was found in plots treated with $L$. lecani followed by B. bassiana (14.62). The maximum losses $(23.52 \%)$ due to the pest was found in untreated plot, whereas it was minimum in plot treated with neem oil (2.26 $\%)$. The details of Incremental Cost Benefit Ratio (ICBR) calculated for different treatments of bio-pesticides are presented in Table 3. Data indicated that maximum realization was found in the treatment of azadirachtin $0.0006 \%$ (₹ $12180 /$ ha) followed by neem oil $0.3 \%$ (₹ $11010 / \mathrm{ha}$ ). While, minimum realization was obtain from the $L$. lecanii $2 \times 10^{8} \mathrm{cfu} / \mathrm{g}$ (₹ 4890/ha). Maximum ICBR was registered in neem oil $0.3 \%$ (1: 8.19 ) followed by tobacco decoction $2 \%$ (1:6.73). While, lowest ICBR was recorded in the plot treated with L. lecanii $2 \times 10^{8} \mathrm{cfu} / \mathrm{g}$ (1: 1.69) followed by $B$. bassiana $2 \times 10^{8} \mathrm{cfu} / \mathrm{g}$ (1: 2.26).

Patel (2002) reported that out of seven azadirachtin based formulations, Gronim $0.075 \%$ (azadirachtin $0.15 \quad$ EC) proved relatively superior in suppressing the population of $A$. gossypii on isabgol. While Patel (2014) reported that the treatment of azadirachtin 0.15 EC (Gronim $0.4 \%$ ) was superior for the control of $A$. gossypii infesting isabgol. According to Sharma et al., (2012), the minimum aphid (A. craccivora) infestation on fenugreek was in the treatment of neem oil (1\%) and it was significantly superior over karanj oil 1\%, garlic bulb extract $5 \%$ and neem leaf extract $5 \%$.

Dalwadi et al., (2008) observed significantly least incidence of $A$. craccivora in Indian bean plots treated with NSKE $5 \%$ followed by NLE. While, in present study, NSKE $5 \%$ and NLE $10 \%$ proved moderately effective. Patil and Patel (2013) also reported that among all the tested botanical insecticides, neem oil @ 0.5 per cent was superior to other botanicals and registered maximum (7.21 q/ha) seed yield. Selvaraj et al., (2010) reported that $B$. bassiana had significantly reduced the aphid population in fenugreek crop. While, El-Salam et al., (2012) reported $V$. lecanii as the most effective treatment followed by Nimbecidine, $M$. anisopliae, $P$. fumosoroseus and the least effective was $B$. bassiana against $A$. craccivora in broad bean.

The treatment of azadirachtin $0.0006 \%$ was found most effective followed by neem oil $0.3 \%$ and garlic bulb extract $3 \%$ for the control of aphid population, producing seed yield and net realization. Entomopathogenic fungi, L. lecanii $2 \times 10^{8} \mathrm{cfu} / \mathrm{g}$ and $B$. bassiana $2 \times 10^{8} \mathrm{cfu} / \mathrm{g}$ proved to be less effective and failed to control the pest, whereas neem seed kernel extract $5 \%$ and tobacco decoction $2 \%$ proved moderately effective against $A$. craccivora on fenugreek crop. Maximum ICBR was registered in neem oil $0.3 \%$ followed by tobacco decoction $2 \%$ and NSKE $5 \%$. While, lowest ICBR was recorded in the plot treated with L. lecanii $2 \times 10^{8} \mathrm{cfu} / \mathrm{g}$ followed by B. bassiana $2 \times 10^{8} \mathrm{cfu} / \mathrm{g}$. 


\section{Acknowledgement}

We are sincerely thankful to Dr. Sunil Joshi, Taxonomist, National Bureau of Agriculturally Important Insects, Bangalore for identification of aphid species, (Aphis craccivora Koch) infesting fenugreek crop. We are also thankful to Dr. R. R. Acharya, I/C, Research Scientist (Veg.), Main Vegetables Research Station for providing experimental farm and other resources.

\section{References}

Ahmad, A., Alghamdi, S. S., Mahmood, K., and Muhammad, A. (2015). Fenugreek a multipurpose crop: Potentialities and improvements. Saudian Journal of Biological Science, pp. 1-11. http://dx.doi.org/10.1016/j.sjbs.2015.09.015.

Anonymous (2015). Agro products/ Spices crops/ Fenugreek/ http://www.agriculturalproductsindia.com/sp ices/spices-fungreek.html.

Dalwadi, M. M., Korat D. M. and Tank, B. D. (2008). Bio-efficacy of some botanical insecticides against major insect pests of indian bean, Lablab purpureus L. Karnataka Journal of Agricultural Science, 21 (2), 295296.

El-Salam, A. M. E., Salem, S. A. and El-Kholy, M. Y. (2012). Efficiency of Nimbecidine and certain entomopathogenic fungi formulations against bean aphids, Aphis craccivora in broad bean field. Archives of Phytopathology and Plant Protection, 45 (19), 2272-2277. http://dx.doi.org/10.1080/03235408.2012.72 6144.
Manjula, K, N., Kotikal, Y. K., Patil, H. B., and Biradar, I. B. (2015). Studies on insect fauna, their natural enemies and pollinators in fenugreek. Karnataka Journal of Agricultural Science, 28 (2), 279-281.

Patel, H. M. (2002). Bio-ecology and management of Aphis gossypii Glover infesting medicinal crop isabgol, Plantago ovata Forskel. [M.Sc. (Agri.) thesis submitted to the Gujarat Agricultural University, Sardarkrushinagar (Unpublished)].

Patel, S. R. (2014). Seasonal abundance and ecofriendly management of aphid, Aphis gossypii Glover infesting isabgol, Plantago ovata Forskel. [M. Sc. (Agri.) thesis (Unpublished) submitted to the Anand Agricultural University, AAU, Anand].

Patil, S. J. and Patel, B. R. (2013). Evaluation of different synthetic and botanical insecticides against aphid, Aphis gossypii Glover infesting isabgol crop. The Bioscan, 8 (2), 705-707.

Poul, M. D. (1976). Studies on the chemical control of mustard pests. Indian Journal of Plant Protection, 14 (1): 9-14.

Selvaraj, K., Kaushik, H. D., Gulati R. and Sharma S. S. (2010). Bioefficacy of Beauveria bassiana (Balsamo) Vuillemin against Hyadaphis coriandri (Das) on Coriander and Aphis craccivora Koch on Fenugreek. Journal of. Biological Control, 24 (2), 142-146. DOI: $10.18641 / j \mathrm{bc} / 24 / 2 / 40154$.

Sharma, S. K., Trivedy, A., Ameta, O. P., Sharma, S. K., Choudhary, R. and Hussain, T. (2012). Evaluation of botanical extract against aphid management in fenugreek under organic farming. Indian Journal of Applied Entomology, 26 (2), 88-92.

\section{How to cite this article:}

Sarvaiya, R.M., N.P. Rathod and Patel, R.M. 2018. Bio-Efficacy of Bio-Pesticides against Aphid, Aphis craccivora Koch Infesting Fenugreek. Int.J.Curr.Microbiol.App.Sci. 7(10): 26342640. doi: https://doi.org/10.20546/ijcmas.2018.710.306 